\title{
Effect of Irrigation and Potash Levels on Keeping Quality of Potato
}

\author{
Ram Chandra Adhikari ${ }^{1}$ and Mahesh Kumar Rana ${ }^{2}$
}

${ }^{1}$ Nepal Agricultural Research Council, Singh Durbar Plaza, Kathmandu, Nepal; @: rcadhikari7@gmail.com, ORCID: https://orcid.org/0000-0001-5805-1298

2Department of Vegetable Science, CCS Haryana Agricultural University, Haryana, India; mkrlotus@gmail.com

Received 01 Nov 2018, Revised 12 Oct 2019, Accepted 14 Feb 2020, Published 17 March 2020

Scientific Editors: Umesh Kumar Acharya, Subash Subedi

Copyright $(2020$ NARC. Permits unrestricted use, distribution and reproduction in any medium provided the original work is properly cited.

The authors declare that there is no conflict of interest.

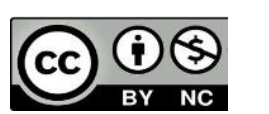

OPEN ACCESS

Licensed under the Creative Commons AttributionNonCommercial 4.0 International (CC BY-NC 4.0)

\section{ABSTRACT}

Irrigation and fertilizer are the most dominating factors, in deciding the keeping quality of potato. It is, therefore, essential to formulate the efficient, reliable and economically viable irrigation management strategy with the use of potassium nutrient in order to produce better keeping quality. The investigation comprising four levels of irrigation (25, 30, 35 and $40 \mathrm{~mm} \mathrm{CPE} \mathrm{(Cumulative} \mathrm{pan} \mathrm{evaporation)} \mathrm{and} \mathrm{four}$ levels of potash $(0,100,125$ and $150 \mathrm{~kg} / \mathrm{ha})$ was carried out at Research Farm of the Department of Vegetable Science, CCS Haryana Agricultural University, (Haryana) Hisar, India during two years to find out the optimum level of irrigation and potash for obtaining higher yield of potatoes with better keeping quality at ambient room temperature. The potato variety used for the investigation was Kufri Bahar. The treatments were laid out in a split plot design with three replications. The increasing levels of irrigation and potash showed significant improvement in keeping quality parameters of potato. Likewise, the values for physiological loss in weight and decay loss of potato tubers (\%) at 15, 30, 45 and 60 days after harvest were the lowest with irrigation level $40 \mathrm{~mm}$ CPE and application of potash @ $150 \mathrm{~kg} / \mathrm{ha}$. The two years results suggest that the irrigation level $40 \mathrm{~mm}$ CPE along with potash @ 150 $\mathrm{kg} / \mathrm{ha}$ has shown the best treatment combination for the storage of potato at ambient room temperature under semiarid conditions of Hisar (Haryana).

Keywords: Irrigation, decay loss, physiological loss, potato, potash

\section{सारांश}

खेतबारीबाट आलु खनेपछी घरके कोठाको परिबेसमा राखदा असर पार्ने विभित्र कारक छन् त्यी मध्ये आलुबालीमा सिंचाई र मलखाद प्रमुख हुन् त्यसैले गर्दा आलु खेतीमा प्रभावकारी, भरपर्दो र आर्थिक रुपले कारगर सिंचाईको साथसाथै पोटास मलखादको रणनैतिक प्रयोगको आबश्यक छ | भारतको चौधरी चरण सिंह हरियाणा कृषि विश्वबिद्यालय, हिसारमा सिंचाईमा भाँडोबाट कुल पानी बास्पिकरणका चार तह (२Y, ३०, ३४ र ४० मी. मी.) र पोटास मलखादका चार तह (०, १००, १२४ र १४० के. जी/हे.) मध्ये कुन तह उपयुक्त हुन्छन् भनि दुई वर्ष अध्ययन गरिएको थियो। अध्ययनको लागि कुफ्री बहार जातको आलुको लगाइएको थियो | अनुसन्धान परिक्षणको नतिजा अनुसार बढ्दो तहको सिंचाइ ( $४ ०$ मी.मी. कुल पानी बास्पिकरण र पोटास (१५० के जी./हे.) को प्रयोग गर्दा आलुलाई घरके कोठामा राखदा पनि ६० दिनसम्म भण्डारणमा गर्न सकिने पाइयो।

\section{INTRODUCTION}

A healthy crop of potato removes potassium (K) about $170-230 \mathrm{~kg} / \mathrm{ha}$, indicating requirement of $\mathrm{K}$ much higher than that of cereals. As such potato invariably responds to potassium application in the various kinds of soil and agro-climatic conditions, in which, it is grown. Potassium increases the size 
but not the total number of tubers (Trehan et al 2001). In India, application of $\mathrm{K}$ tended to decrease gradually the weight loss of tubers from 20 to $16 \%$ (Grewal et al 1991) during post-harvest period. In other experiment, dry matter loss with application of potassium $100 \mathrm{~kg} / \mathrm{ha}$ was only $5.6 \%$ as compared to $20.3 \%$ without $\mathrm{K}$ application (Perrenoud 1993) in field condition. The need of potassium by the crop varies with the agro-climatic region, variety, crop sequence and soil type. Under the conditions of high crop intensity and high rates of $\mathrm{K}$ removal, soils are likely to become deficient in $\mathrm{K}$ with time. Maximum accumulation of $\mathrm{K}$ takes place between 30 and 60 days of planting in the plains and between 65 and 85 days in the hills (Grewal and Trehan 1993).

Being a shallow rooted crop, fertilizer use efficiency for potash ranges between 50 and $60 \%$ (uptake efficiency), demanding frequent irrigation under north plain conditions of India. However, soil moisture availability is the main constraint for growing profitable crops in this area during winter season. Rainfall during potato growing period is meager and erratic. Therefore, water-saving measures that can enhance both potato yield and quality play an important role in different agro climatic regions particularly in arid and semi-arid regions. Improper irrigation management practices not only waste the expensive and scarce water resources but also reduce the tuber yield and quality (Singh et al 2002). Therefore, proper irrigation scheduling in potato is one of the most important factor. Potash also improves the shipping quality, extends shelf life and reduces the losses of potato in storage (Perrenoud 1993). Application of potash before planting tends to reduce weight loss of potato gradually from 20 to $16 \%$ (Grewal et al 1991). Tarafdar et al (1988) found that irrigation at moisture tensions of $0.3,0.6$ or 0.9 atm. and use of potassium $0-240 \mathrm{~kg} / \mathrm{ha}$, tuber yield decreased with increasing water stress regardless of $\mathrm{K}$ rate and also uptake increases with increasing $\mathrm{K}$ rate but decreases with decreasing soil water quantity. Khalak and Kumaraswamy (1996) found that application of potassium $150 \mathrm{~kg} / \mathrm{ha}$ gave the highest water use efficiency but the lowest consumptive water use. The effect of potash on shelf life was dominantly favorable, both through slowing of senescence and through decreasing of numerous physiological disorders. Therefore, it was essential to formulate the efficient, reliable, and economically viable irrigation management strategy with the use of potassium fertilizer in order to improve keeping quality, which can be achieved best with the use of potassium and suitable irrigation scheduling under limited water resources.

\section{MATERIALS AND METHODS}

The present experiment was conducted at Research Farm of the Department of Vegetable Science, Hisar during the year 2011 and 2012 in split plot design with three replications. Individual sub-plot was consisted of $12.96 \mathrm{~m}^{2}(3.60 \times 3.60 \mathrm{~m})$, having 6 rows and each row containing 18 plants. The treatment combinations were consisted of four irrigation levels $(25,30,35$ and $40 \mathrm{~mm} \mathrm{CPE})$ and four potash levels $(0,100,125$ and $150 \mathrm{~kg} / \mathrm{ha})$. The crop was planted on 25 October in 2010 and $1 \mathrm{st}$ November in 2011. Two third dose of nitrogen and full doses of phosphorus and potash were applied at the time of planting in furrows. The remaining one third dose of nitrogen was top dressed 5 weeks after planting. Disease free pre-sprouted seed tubers of variety Kufri Bahar weighing approximately $40-60 \mathrm{~g}$ were planted at a row and plant spacing of $60 \times 20 \mathrm{~cm}$. The potato plants were dehaulmed 100 days after planting, and the crop was harvested 15 days after dehaulming. The storage experiment was conducted from March 29 to May 28 in 2011 and March 14 to May 13 in 2012. Five kilogram clean and uniform size tubers from each treatment were packed individually in jute bags and kept at room temperature in three replications. The five randomly selected tubers in each bag were individually marked and numbered. The marked tubers were weighted at 15, 30, 45 and 60 days after harvest. The initial weight of each marked tuber was recorded at the beginning of experiment to determine the physiological loss in weight. The percent weight loss was obtained by taking difference between the initial and final weight over the initial weight multiplied by 100. Similar to physiological loss in weight, the percentage of decayed tubers was determined based on the weight of decayed tubers over total weight of the tubers multiplied by 100 . The data recorded for physiological loss in weight and decay loss were analyzed by using the techniques of analysis of variance (ANOVA) as suggested by Gomez and Gomez (1984) and analysed using OPSTAT (1998). 


\section{RESULTS}

The minimum and maximum temperature and relative humidity during storage period in 2011 ranged from 15.0 to 27.0 and 32.10 to $42.90^{\circ} \mathrm{C}$, and $33-57$ and $46-87 \%$, and during 2012 , from 8.0 to 21.50 and 24.9 to $34.40^{\circ} \mathrm{C}$ and $24-50$ and $58-88 \%$, respectively.

\section{Physiological Loss in Weight}

Physiological loss in weight progressively increased up to 60 days of storage (DOS) at ambient room temperature. The perusal of data presented in Table 1 reveals that all the irrigation levels differed significantly from each other during both the years with respect to physiological loss in weight of potato tubers at 15, 30, 45 and 60 days after harvest at ambient room temperature. The mean physiological loss in weight due to irrigation levels increased from 1.55 to $12.22 \%$ between 15 and 60 days of storage during 2011, while in 2012, it increased from 1.54 to $10.01 \%$ (Table 1). The minimum mean value for physiological loss in weight of tubers at 15 (1.55 and 1.54\%), 30 (3.58 and $3.27 \%), 45(6.87$ and $5.71 \%$ ) and 60 days (7.69 and 6.32\%) after harvest was recorded with irrigation level $40 \mathrm{~mm}$ CPE, while the maximum mean value for physiological loss in weight of tubers at 15 (1.99 and 1.94\%), 30 (4.37 and 3.79\%), 45 (7.69 and 6.32\%) and 60 days (12.22 and 10.01\%) after harvest at ambient room temperature was recorded with irrigation level $25 \mathrm{~mm} \mathrm{CPE}$ in 2011 and 2012, respectively.

Table 1. Effect of irrigation and potash levels on physiological loss in weight $(\%)$ of potato tubers at $\mathbf{1 5}$, 30, 45 and 60 days after harvest at ambient room temperature

Days to physiological loss in weight $(\%)$ after harvest in storage

Treatment 2011 2012

\begin{tabular}{|c|c|c|c|c|c|c|c|c|}
\hline & & & & & \\
\hline & 15 & 30 & 45 & 60 & 15 & 30 & 45 & 60 \\
\hline \multicolumn{9}{|c|}{ Irrigation levels (I) } \\
\hline $25 \mathrm{~mm} \mathrm{CPE}\left(\mathrm{I}_{1}\right)$ & 1.99 & 4.37 & 7.69 & 12.22 & 1.94 & 3.79 & 6.32 & 10.01 \\
\hline $30 \mathrm{~mm} \mathrm{CPE}\left(\mathrm{I}_{2}\right)$ & 1.81 & 4.24 & 7.55 & 11.17 & 1.84 & 3.69 & 6.18 & 9.55 \\
\hline $35 \mathrm{~mm} \mathrm{CPE}\left(\mathrm{I}_{3}\right)$ & 1.75 & 3.91 & 7.21 & 10.83 & 1.64 & 3.42 & 5.90 & 9.18 \\
\hline $40 \mathrm{~mm} \mathrm{CPE}\left(\mathrm{I}_{4}\right)$ & 1.55 & 3.58 & 6.87 & 10.14 & 1.54 & 3.27 & 5.71 & 8.46 \\
\hline CD at $5 \%$ level & 0.10 & 0.09 & 0.12 & 0.32 & 0.08 & 0.10 & 0.13 & 0.33 \\
\hline \multicolumn{9}{|l|}{ Potash levels (K) } \\
\hline $0 \mathrm{~kg} / \mathrm{ha}\left(\mathrm{K}_{1}\right)$ & 1.97 & 4.40 & 7.75 & 11.99 & 2.03 & 3.86 & 6.32 & 10.38 \\
\hline $100 \mathrm{~kg} / \mathrm{ha}\left(\mathrm{K}_{2}\right)$ & 1.84 & 4.12 & 7.45 & 11.35 & 1.81 & 3.63 & 6.18 & 9.57 \\
\hline $125 \mathrm{~kg} / \mathrm{ha}\left(\mathrm{K}_{3}\right)$ & 1.69 & 3.92 & 7.21 & 10.75 & 1.64 & 3.44 & 5.9 & 8.94 \\
\hline $150 \mathrm{~kg} / \mathrm{ha}\left(\mathrm{K}_{4}\right)$ & 1.58 & 3.66 & 6.93 & 10.27 & 1.48 & 3.25 & 5.71 & 8.31 \\
\hline CD at $5 \%$ level & 0.08 & 0.08 & 0.12 & 0.22 & 0.06 & 0.10 & 0.10 & 0.24 \\
\hline \multicolumn{9}{|l|}{ Interaction (IxK) } \\
\hline $\mathrm{I}_{1} \times \mathrm{K}_{1}$ & 2.26 & 4.78 & 8.16 & 13.26 & 2.30 & 4.19 & 6.76 & 11.38 \\
\hline $\mathrm{I}_{1} \times \mathrm{K}_{2}$ & 2.05 & 4.41 & 7.76 & 12.49 & 2.02 & 3.89 & 6.44 & 10.25 \\
\hline $\mathrm{I}_{1} \times \mathrm{KK}_{3}$ & 1.92 & 4.26 & 7.54 & 11.81 & 1.82 & 3.65 & 6.17 & 9.54 \\
\hline $\mathrm{I}_{1} \times \mathrm{K}_{4}$ & 1.72 & 4.04 & 7.30 & 11.33 & 1.62 & 3.42 & 5.92 & 8.88 \\
\hline $\mathrm{I}_{2} \times \mathrm{K}_{1}$ & 2.09 & 4.55 & 7.91 & 12.27 & 2.12 & 3.99 & 6.51 & 10.53 \\
\hline $\mathrm{I}_{2} \mathrm{xK}_{2}$ & 1.88 & 4.32 & 7.65 & 11.60 & 1.91 & 3.77 & 6.27 & 9.91 \\
\hline $\mathrm{I}_{2} \times \mathrm{K}_{3}$ & 1.73 & 4.14 & 7.44 & 10.70 & 1.75 & 3.60 & 6.08 & 9.20 \\
\hline $\mathrm{I}_{2} \times \mathrm{K}_{4}$ & 1.54 & 3.93 & 7.21 & 10.10 & 1.59 & 3.42 & 5.87 & 8.54 \\
\hline $\mathrm{I}_{3} \times \mathrm{K}_{1}$ & 1.86 & 4.26 & 7.60 & 11.57 & 1.91 & 3.71 & 6.23 & 10.18 \\
\hline $\mathrm{I}_{3} \times \mathrm{K}_{2}$ & 1.82 & 4.02 & 7.33 & 10.96 & 1.71 & 3.50 & 6.00 & 9.50 \\
\hline $\mathrm{I}_{3} \times \mathrm{K}_{3}$ & 1.68 & 3.85 & 7.14 & 10.56 & 1.54 & 3.32 & 5.77 & 8.85 \\
\hline $\mathrm{I}_{3} \mathrm{XK}_{4}$ & 1.63 & 3.52 & 6.79 & 10.22 & 1.39 & 3.15 & 5.58 & 8.19 \\
\hline $\mathrm{I}_{4} \times \mathrm{K}_{1}$ & 1.68 & 4.02 & 7.32 & 10.86 & 1.78 & 3.53 & 6.00 & 9.44 \\
\hline $\mathrm{I}_{4} \times \mathrm{KK}_{2}$ & 1.62 & 3.75 & 7.05 & 10.34 & 1.62 & 3.35 & 5.80 & 8.60 \\
\hline
\end{tabular}




\begin{tabular}{lcccccccc}
\hline & \multicolumn{6}{c}{ Days to physiological loss in weight $(\%)$ after harvest in storage } \\
\cline { 2 - 10 } Treatment & \multicolumn{6}{c}{$\mathbf{2 0 1 1}$} & \multicolumn{3}{c}{$\mathbf{2 0 1 2}$} \\
& $\mathbf{1 5}$ & $\mathbf{3 0}$ & $\mathbf{4 5}$ & $\mathbf{6 0}$ & $\mathbf{1 5}$ & $\mathbf{3 0}$ & $\mathbf{4 5}$ & $\mathbf{6 0}$ \\
\hline $\mathrm{I}_{4} \times K_{3}$ & 1.45 & 3.42 & 6.71 & 9.93 & 1.45 & 3.18 & 5.61 & 8.17 \\
\hline $\mathrm{I}_{4} \times K_{4}$ & 1.44 & 3.14 & 6.41 & 9.43 & 1.32 & 3.03 & 5.44 & 7.63 \\
\hline $\mathbf{C D}, \mathbf{5 \%}$ & $\mathbf{0 . 1 6}$ & $\mathbf{0 . 1 6}$ & $\mathbf{0 . 2 4}$ & $\mathbf{0 . 4 4}$ & $\mathbf{0 . 1 2}$ & $\mathbf{0 . 2 0}$ & $\mathbf{0 . 2 0}$ & $\mathbf{0 . 4 8}$ \\
\hline
\end{tabular}

The physiological loss in weight of tubers grown with frequent irrigation supply was high because of high moisture content of the tubers. However, in 2011, there was no significant difference between irrigation levels, i.e., $30(1.81 \%)$ and $35 \mathrm{~mm} \mathrm{CPE} \mathrm{(1.75 \% )} \mathrm{with} \mathrm{respect} \mathrm{to} \mathrm{physiological} \mathrm{loss} \mathrm{in} \mathrm{weight}$ of potato tubers at 15 days after harvest under ambient room temperature conditions. The irrigation level 25 (3.79\%) and $30 \mathrm{~mm} \mathrm{CPE} \mathrm{(3.69 \% )} \mathrm{were} \mathrm{statistically} \mathrm{similar} \mathrm{with} \mathrm{respect} \mathrm{to} \mathrm{physiological} \mathrm{loss}$ in weight of potato tubers at 30 days after harvest under ambient room temperature conditions in 2012. The levels of potash differed significantly from each other with respect to physiological loss in weight of tubers at 15, 30, 45 and 60 days after harvest at ambient room temperature (Table 1). The minimum physiological loss in weight of tubers at 15 (1.58 and 1.48\%), 30 (3.66 and 3.25\%), 45 (6.93 and 5.70\%) and $60(10.27$ and 10.38\%) days after harvest at ambient room temperature was registered with potash @ $150 \mathrm{~kg} / \mathrm{ha}$, whereas, the maximum physiological loss in weight of tubers at 15 (1.97 and 2.03\%), 30 (4.40 and 3.86\%), 45 (7.75 and 6.38\%) and 60 (11.99 and 10.38\%) days after harvest at ambient room temperature was recorded with no potash application during 2011 and 2012, respectively.

\section{Decay Loss}

The perusal of data presented in Table 2 reveals that all the irrigation treatments differed significantly from each other during 2011, while no loss due to decaying of tubers was observed at all the dates of observation, i.e., 15, 30, 45 and 60 days after harvest, at ambient room temperature during the year 2012. The increase in irrigation level up to $40 \mathrm{~mm}$ CPE significantly reduced the decay loss of potato tubers at all the dates of observation at ambient room temperature. The minimum mean value for decay loss of tubers at $15,30,45$ and 60 days after harvest $(0.31,1.45,6.10$ and $16.37 \%$, respectively) was recorded with irrigation level $40 \mathrm{~mm} \mathrm{CPE}$ and the maximum mean value $(1.36,4.49,9.90$ and $29.70 \%$, respectively) with irrigation level $25 \mathrm{~mm}$ CPE. This might be due to that the excessive soil moisture is conducive for the multiplication of many decay causing pathogens, and simultaneously, excessive moisture on crop canopy encourages the incidence of diseases. The irrigation level 25 $(1.36 \%)$ and $30 \mathrm{~mm}$ CPE (1.28\%) and $35(0.36 \%)$ and $40 \mathrm{~mm}$ CPE $(0.56 \%)$ were statistically similar with each other at 15 days after harvest. Similarly, the irrigation level $25(25.1 \%)$ and $30 \mathrm{~mm} \mathrm{CPE}$ $(24.1 \%)$ were statistically at par with each other with respect to decay loss of potato tubers at 60 days after harvest under ambient room temperature conditions.

All the treatments pertaining to potash levels differed significantly from each other with respect to decay loss at 15, 30, 45 and 60 days after harvest during 2011 but no loss was observed due to decaying during 2012 (Table 2). The minimum decay loss of tubers at 15, 30, 45 and 60 days after harvest under ambient room temperature conditions was recorded with potash applied @ $150 \mathrm{~kg} / \mathrm{ha}$ $(0.56,2.68,7.10$ and $18.24 \%$, respectively) and the maximum decay loss of potato tubers with no application of potash $(1.45,4.18,9.82$ and $26.11 \%$, respectively).

Table 2: Effect of irrigation and potash levels on decay loss (\%) of potato tubers at 15, 30, 45 and 60 days after harvest under ambient room temperature

\begin{tabular}{|c|c|c|c|c|c|c|c|c|}
\hline \multirow[t]{3}{*}{ Treatment } & \multicolumn{8}{|c|}{ Days to decay loss in weight $(\%)$ after harvest in storage } \\
\hline & \multicolumn{4}{|c|}{2011} & \multicolumn{4}{|c|}{2012} \\
\hline & 15 & 30 & 45 & 60 & 15 & 30 & 45 & 60 \\
\hline \multicolumn{9}{|c|}{ Irrigation levels (I) } \\
\hline $25 \mathrm{~mm} \mathrm{CPE}\left(\mathrm{I}_{1}\right)$ & 1.36 & 4.49 & 9.90 & 25.08 & 0 & 0 & 0 & 0 \\
\hline $30 \mathrm{~mm} \mathrm{CPE}\left(\mathrm{I}_{2}\right)$ & 1.28 & 4.23 & 9.50 & 24.07 & 0 & 0 & 0 & 0 \\
\hline
\end{tabular}




\begin{tabular}{|c|c|c|c|c|c|c|c|c|}
\hline \multirow[t]{3}{*}{ Treatment } & \multicolumn{8}{|c|}{ Days to decay loss in weight (\%) after harvest in storage } \\
\hline & \multicolumn{4}{|c|}{2011} & \multicolumn{4}{|c|}{2012} \\
\hline & 15 & 30 & 45 & 60 & 15 & 30 & 45 & 60 \\
\hline $35 \mathrm{~mm} \mathrm{CPE}\left(\mathrm{I}_{3}\right)$ & 0.36 & 3.05 & 7.77 & 20.81 & 0 & 0 & 0 & 0 \\
\hline $40 \mathrm{~mm} \mathrm{CPE}\left(\mathrm{I}_{4}\right)$ & 0.31 & 1.45 & 6.10 & 16.37 & 0 & 0 & 0 & 0 \\
\hline CD at $5 \%$ level & 0.17 & 0.20 & 0.33 & 1.45 & $\mathbf{0}$ & $\mathbf{0}$ & $\mathbf{0}$ & $\mathbf{0}$ \\
\hline \multicolumn{9}{|l|}{ Potash levels (K) } \\
\hline $0 \mathrm{~kg} / \mathrm{ha}\left(\mathrm{K}_{1}\right)$ & 1.45 & 4.18 & 9.82 & 26.11 & 0 & 0 & 0 & 0 \\
\hline $100 \mathrm{~kg} / \mathrm{ha}\left(\mathrm{K}_{2}\right)$ & 0.68 & 3.25 & 8.46 & 21.94 & 0 & 0 & 0 & 0 \\
\hline $125 \mathrm{~kg} / \mathrm{ha}\left(\mathrm{K}_{3}\right)$ & 0.61 & 3.13 & 7.90 & 20.04 & 0 & 0 & 0 & 0 \\
\hline $150 \mathrm{~kg} / \mathrm{ha}\left(\mathrm{K}_{4}\right)$ & 0.56 & 2.68 & 7.10 & 18.24 & 0 & 0 & 0 & 0 \\
\hline CD at 5\% level & 0.12 & 0.16 & 0.27 & 1.06 & $\mathbf{0}$ & $\mathbf{0}$ & $\mathbf{0}$ & $\mathbf{0}$ \\
\hline \multicolumn{9}{|l|}{ Interaction (IxK) } \\
\hline $\mathrm{I}_{1} \times \mathrm{K}_{1}$ & 1.63 & 4.85 & 11.00 & 29.72 & 0 & 0 & 0 & 0 \\
\hline $\mathrm{I}_{1} \times \mathrm{K}_{2}$ & 1.40 & 4.48 & 10.16 & 25.44 & 0 & 0 & 0 & 0 \\
\hline $\mathrm{I}_{1} \times \mathrm{K}_{3}$ & 1.24 & 4.39 & 9.55 & 23.52 & 0 & 0 & 0 & 0 \\
\hline $\mathrm{I}_{1} \mathrm{XK}_{4}$ & 1.16 & 4.23 & 8.91 & 21.64 & 0 & 0 & 0 & 0 \\
\hline $\mathrm{I}_{2} \mathrm{xK}_{1}$ & 1.52 & 4.64 & 10.48 & 27.68 & 0 & 0 & 0 & 0 \\
\hline $\mathrm{I}_{2} \mathrm{xK}_{2}$ & 1.33 & 4.31 & 9.76 & 24.37 & 0 & 0 & 0 & 0 \\
\hline $\mathrm{I}_{2} \mathrm{xK}_{3}$ & 1.20 & 4.09 & 9.11 & 23.04 & 0 & 0 & 0 & 0 \\
\hline $\mathrm{I}_{2} \mathrm{xK}_{4}$ & 1.08 & 3.89 & 8.65 & 21.20 & 0 & 0 & 0 & 0 \\
\hline $\mathrm{I}_{3} \mathrm{xK}_{1}$ & 1.43 & 4.27 & 9.69 & 25.25 & 0 & 0 & 0 & 0 \\
\hline $\mathrm{I}_{3} \mathrm{xK}_{2}$ & 0.00 & 2.72 & 7.64 & 21.55 & 0 & 0 & 0 & 0 \\
\hline $\mathrm{I}_{3} \mathrm{xK}_{3}$ & 0.00 & 2.64 & 7.12 & 19.11 & 0 & 0 & 0 & 0 \\
\hline $\mathrm{I}_{3} \mathrm{xK}_{4}$ & 0.00 & 2.59 & 6.64 & 17.32 & 0 & 0 & 0 & 0 \\
\hline $\mathrm{I}_{4} \mathrm{xK}_{1}$ & 1.23 & 2.95 & 8.11 & 21.79 & 0 & 0 & 0 & 0 \\
\hline $\mathrm{I}_{4} \mathrm{xK}_{2}$ & 0.00 & 1.48 & 6.28 & 16.40 & 0 & 0 & 0 & 0 \\
\hline $\mathrm{I}_{4} \mathrm{xK}_{3}$ & 0.00 & 1.39 & 5.84 & 14.51 & 0 & 0 & 0 & 0 \\
\hline $\mathrm{I}_{4} \mathrm{XK}_{4}$ & 0.00 & 0.00 & 4.19 & 12.79 & 0 & 0 & 0 & 0 \\
\hline CD, $5 \%$ & 0.24 & $\mathbf{0 . 3 2}$ & 0.54 & 2.12 & $\mathbf{0}$ & $\mathbf{0}$ & $\mathbf{0}$ & 0 \\
\hline
\end{tabular}

\section{DISCUSSION}

A gradual increase in weight loss of tubers during storage was also reported by Mehta and Singh (2002) and Rastovski (1987). The increased weight loss in this study could be attributed to low relative humidity and high temperature during storage. It is suggested that cold stores maintained at 2$4^{\circ} \mathrm{C}$ should be used exclusively for the storage of seed potatoes. Table and processing potatoes should be stored at $8-12^{\circ} \mathrm{C}$ and $90-95 \%$ relative humidity because at this temperature sprouting does not occur and weight loss is minimum (Ezekiel et al 1999).

Diminished moisture loss during storage is regarded as an important potato quality character since it keeps the weight and shape of potato tubers maintained. Potash application may help in conserving tuber moisture as it acts as an osmoticum (Mengel and Kirkby 1987), protecting the tuber moisture from being lost. Physiological loss in weight is the manifest of dry matter or moisture content and hardening of tuber skin. Since potash application had a beneficial effect on dry matter content, the reduction in physiological loss in weight could be understood. Potash application reduces storage losses of tubers, and this was related to reduction in the activity of catalase and peroxidase enzymes (Perrenoud 1993). The application of potash @ $150 \mathrm{~kg} / \mathrm{ha}$ reduced the storage losses significantly at 4 weeks after harvest (Bansal and Umar 1998). Potassium has a crucial role in the energy status of the plant, translocation and storage of assimilates and maintenance of tissue water relations (Marschner 1995). Potassium is not an incorporated component of plant molecules, in opposite to $\mathrm{N}$ and $\mathrm{P}$, which 
are constituents of proteins, nucleic acids, phospholipids, ATP, etc. Potassium predominantly exists as a free or absorptive bound cation, and thus, can be displaced very easily on the cellular level as well as in the whole plant (Lindhauer 1985). This high mobility in the plant explains the major functional characteristics of potassium as the main cation involved in the neutralization of charges and as the most important inorganic osmotic active substance (Clarkson and Hanson, 1980). Potassium has a crucial role in energy status of the plant, translocation and storage of assimilates and maintenance of tissue water relations (Marschner 1995).

Potassium is involved in many aspects of the plant physiology (Marschner 1995), activates more than 60 enzyme systems, aids in photosynthesis, favors high energy status, maintains cell turgor, regulates opening of leaf stomata, promotes water uptake, regulates nutrients translocation in plant, favors carbohydrate transport and storage, enhances $\mathrm{N}$ uptake and protein synthesis, promotes starch synthesis. These multiple functions of $\mathrm{K}$ in many metabolic processes lead to numerous positive effects of an adequate $\mathrm{K}$ nutrition for potato, increases yield, proportion of marketable tubers and tuber size, decreases internal blackening and hollow heart, mechanical damages to tubers and storage losses, enhances shipping quality and extends shelf life, improves cooking and processing qualities, chips colour, resistance to frost and drought, decreases incidence of diseases (late blight) and improves $\mathrm{N}$ use efficiency. After harvesting, the physiological loss in weight is a major problem in handling and marketing of potato tubers. Weight loss of 3.10 to $4.80 \%$ during storage is quite acceptable (Ezekiel and Dahiya 2004), and weight loss up to $0.8 \%$ per month is known to occur in cold stores maintaining temperature $2-4^{\circ} \mathrm{C}$ (Ezekiel et al 2002).

The interaction effects of irrigation and potash levels differed significantly from each other with respect to physiological loss in weight of tubers at 15, 30, 45 and 60 days after harvest under ambient room temperature conditions during both the years. The treatment combination irrigation level $40 \mathrm{~mm}$ CPE along with potash $150 \mathrm{~kg}$ showed the lowest level of interaction effect on physiological loss in weight of tubers at all the dates of observation under ambient room temperature conditions, while the treatment combination irrigation level $25 \mathrm{~mm}$ CPE with no potash application showed the maximum value for physiological loss in weight of tubers at 15,30, 45 and 60 days after harvest under ambient room temperature conditions during 2011 and 2012, respectively (Table 1). Same results were revealed by Martin-Prevel (1989).

The interaction effects of irrigation and potash levels differed significantly from each other with respect to decay loss of potato tubers at 15, 30, 45 and 60 days after harvest at ambient room temperature during the year 2010-11 (Table 2). The treatment combination irrigation level $40 \mathrm{~mm}$ CPE with potash @ $150 \mathrm{~kg} / \mathrm{ha}$ showed the lowest level of interaction effect on decay loss of tubers at 60 days after harvest at ambient room temperature, while the treatment combination irrigation level 25 $\mathrm{mm}$ CPE with no application of potash showed the maximum value for decay loss of potato tubers at 60 days after harvest at ambient room temperature. These results are similar to those reported by Ramink et al (1998).

After harvest, the prevailing high temperature caused heavy decay loss of potato tubers. In 2011, at the time of harvesting from February 13 to March 9, the total rainfall received was $42.7 \mathrm{~mm}$. In addition to this, the minimum and maximum temperature increased, which might have helped in increasing decay loss (\%) of potato tubers at ambient room temperature. The loss in weight of potato tubers due to decaying is influenced by the number of factors such as an amount of decay, presence of diseases and stage of maturity (Beukema and Vander Zaag 1979). Field experiments conducted by Moinuddin et al (2003) indicate that different varieties responded differently to applied potassium, while Kufri Satluj, Kufri Badshah and Kufri Bahar responded potassium up to $150 \mathrm{~kg} / \mathrm{ha}$ but Kufri Kuber responded up to $75 \mathrm{~kg} / \mathrm{ha}$ only and moreover the magnitude of response was much higher in Kufri Satluj and Kufri Badshah than in Kufri Bahar. Kufri Kuber turned to be the least responsive to applied $\mathrm{K}$ as it was also the poorest yielder among all the 4 varieties. Moreover, $\mathrm{K}$ application increased yield of large grade tubers in Kufri Satluj and Kufri Badshah than in Kufri Bahar and Kufri Kuber. 
Potash enhanced the storage and shipping quality of potato tubers and also extended their shelf life. Potash application also reduced the storage loss, which was due to reduction in the activity of catalase and peroxidase enzymes (Perrenoud 1993). The results of present study corroborate the findings of Bansal and Trehan (2011) and Dubey et al (1997), who reported that the application of potash up to $150 \mathrm{~kg} / \mathrm{ha}$ decreased the decaying of tubers linearly during pit storage, and the maximum loss in weight of tubers $(34.80 \%)$ due to decaying was when the potash was not applied. The potash level 100 $(0.68 \%), 125(0.61 \%)$ and $150 \mathrm{~kg} / \mathrm{ha}(0.56 \%)$ were statistically at par with each other at 15 days after harvest, while the potash level $100(3.25 \%)$ and $125 \mathrm{~kg} / \mathrm{ha}(3.13 \%)$ were statistically par with each other with respect to decay loss of potato tubers 30 days after harvest under ambient room temperature conditions. The effects of potassium on shelf life are dominantly favorable, both through slowing of senescence and through a decrease of numerous physiological diseases (Martin-Prevel 1989). Quality of tubers grown for processing into frozen French fries is sensitive to water stress (Eldredge et al 1996, Shock et al 1993). Water stress during early tuber bulking reduces specific gravity and increases reducing sugars associated with dark stem-end fry colour. When the defects, as measured at harvest, exceed contract specifications, grower returns are reduced by contract penalty clauses. Dark-ends may become more severe after tubers have been stored (Eldredge et al 1996). The timing of water stress is important, water stress before tuber initiation has no deleterious effect on tuber quality (Shock et al 1992), while stress later during tuber bulking can cause dark stem-end fry colour and reduced specific gravity (Eldredge et al 1996, Shock et al 1993).

\section{CONCLUSION}

The keeping quality of potatoes can be enhanced by applying irrigation and potash at particular level. Irrigation level $40 \mathrm{~mm} \mathrm{CPE} \mathrm{in} \mathrm{combination} \mathrm{of} \mathrm{potash} 150 \mathrm{~kg} / \mathrm{ha}$ was found the best for storing the potato tubers successfully at ambient room temperature under semi-arid conditions of Haryana since at this level of irrigation and potash the tubers were having less amount of moisture, which favors the long storage of potato tubers.

\section{ACKNOWLEDGEMENTS}

The authors, thanks to the CCS Haryana Agricultural University, Haryana, India for providing the financial support in conducting the field experiment and special thanks to Nepal Agricultural Research Council for rewarding fellowship to conduct the research experiment.

\section{REFERENCES}

Bansal SK and S Umar. 1998. Effect of potassium on yield and quality of potato. Fertilizer News, 43 (11): 4346.

Bansal SK. and SP Trehan. 2011. Effect of potassium on yield and processing quality attributes of potato. Karnataka Journal of Agricultural Science 24 (1): 48-54.

Beukema HP and D.E, Vander-Zaag 1979. Potato improvement. International Agricultural Center. Wageningen, The Netherlands.

Clarkson DT and JB Hanson. 1980. The mineral nutrition of higher plants. Ann. Rev. Plant Physiol. 31: 239298.

Dubey YP, SD Shankhyan and BP Kaistha. 1997. Effect of potassium on yield and storage behavior of potato (Solanum tuberosum L.) in Lahaul valley of Himachal Pradesh. Journal of Potassium Research 13: 273276.

Eldredge EP, ZA Holmes, AR Mosley, CC Shock and TD Stieber. 1996. Effects of transitory water stress on potato tuber stem-end reducing sugar and fry color. Am. Potato J. 73:517-530.

Ezekiel R and P Dahiya. 2004. Storage behavior and processing quality of potatoes stored in heaps and pits in the Malwa region (MP). Potato J. 31 (1-2): 21-28. 
Ezekiel R, PS Dahiya and GS Shekhawat. 2002. Traditional methods of potato storage in the Malwa region of Madhaya Pradesh. Central Potato Research Institute, Shimla, Technical Bulletin 57.

Ezekiel R, V Paul, J Singh and GS Shekhawat. 1999. Potato storage in India. Special issues fifty years of potato research in India, 49 (9): 21

Gomez KA and A Gomez. 1984. Statistical Procedure for Agricultural Research, 2nd edn. John Willy and Sons, New York, USA.

Grewal JS, SP Trehan and RC Sharma. 1991. Phosphorus and Potassium Nutrition of Potato. Central Potato Research Institute, Shimla, Himachal Pradesh, India, Technical Bulletin 31.

Grewal JS and SP Trehan. 1993. Phosphorus and potassium nutrition of potato. In: Adv. in Hort. (Chadha, K.L. and J.S. Grewal Eds.). Malhotra Publishing House, New Delhi. 7:261-297.

Grewal JS, SP Trehan and RC Sharma. 1991. Phosphorus and potassium nutrition of potato. Technical Bulletin 31. Central Potato Research Institute, Shimla, India.

Khalak A. and AS Kumaraswamy. 1996. Water use efficiency and nutrient uptake in potato. Mysore J. of Agri. Sci. 30: 39-42.

Lindhauer MG. 1985. The role of potassium in the plant with emphasis on stress conditions (water, temperature, salinity). In: Proceedings of the Potassium Symposium. Pretoria, October 1985. Department of Agriculture and Water Supply, International Potash Institute and Fertilizer Society of South Africa. pp.95-113.

Marschner H. 1995. Mineral Nutrition of Higher Plants. 2nd Ed. Academic Press, London.

Martin-Prevel PJ. 1989. Physiological processes related to handling and storage quality of crops. In: Proceedings of the 21 st IPI Colloquium on: Methods of K Research in Plants, held at Louvain-la-Neuve, Belgium, 19-21 June 1989. International Potash Institute, Bern, Switzerland. pp.219-248.

Mehta A and SP Singh. 2002. Physiolological losses in potatoes under non-refrigerated storage: Effect of N, P and K fertilizers. Journal of Indian Potato Association 29(3-4):129-134.

Mengel K and EA Kirkby. 1987. Principle of Plant Nutrition, 4th Edn. International Potash Institute, Bern, Switzerland.

Moinuddin Singh, SK Bansal and NS Pasricha. 2003. Influence of graded levels of potassium on growth, yield and economic parameters of potato. Journal of Plant Nutrition 35: 164-172.

OPSTAT. 1998. Statistical Software Package for Agricultural Research Workers. Recent Advances in information theory, Statistics \& Computer Applications by DS Hooda \& RC Hasija Department of Mathematics Statistics, CCS HAU, Hisar, India. pp. 139-143.

Perrenoud S. 1993. Fertilizing for High Yield Potato 2nd Edition. International Potash Institute, Basel, Switzerland, IPI Bulletin No. 8.

Perrenoud S. 1993. Fertilizing for High Yield Potato. IPI Bulletin 8. 2nd Edition. International Potash Institute, Basel, Switzerland.

Ramnik S, YP Dubey, BP Kairstha and R Sharma. 1998. Effect of irrigation and nitrogen on yield attributes, sizeand protein content of tubers of potato (Solatium tubersnin, L.) in Lahaul valley of Himalayas. Annals of Agric Bio-Research 3 (1): 61-66.

Rastovski A. 1987.Storage losses. In: Storage of Potatoes: Post-Harvest Behavior, Store Design, Storage Practice, Handling (Eds. Rastovski, A. and van-Es A.). Pudoc, Wageningen. The Netherlands, pp. 177180.

Shock CC, ZA Holmes, TD Stieber, EP Eldredge and P. Zhang. 1993. The effect of timed water stress on quality, total solids and reducing sugar content of potatoes. American Potato J. 70:227-241.

Shock CC, JD Zalewski, TD Stieber and DS Burnett. 1992. Early season water deficits on Russet Burbank plant development, yield, and quality. American Potato J. 69: 793-804.

Singh N, MC Sood and RC Sharma. 2002. Effect of irrigation levels, cultural practices and nitrogen application on potato production under drip and sprinkler methods of irrigation. In: Potato Global Research and Development, Vol. II (Eds. Khurana SMP, Shekhawat GS, Pandey SK. and Singh BP). Indian Potato Association, Shimla, Himachal Pradesh, India, pp. 923-925. 
Tarafdar, PK, NE Banarjee and AK Mukhopadhyay. 1988. Influence of potassium fertilization on the responds to soil moisture stress in potato. Acta Agronomical Hungarica 37: 1-2.

Trehan, SP, SK Roy and RC Sharma. 2001. Potato variety differences in nutrient deficiency symptoms and responses to NPK. Better Crops International Potash and Phosphate Institute of Canada (PPIC) 15:18-21.

$|1-----|||------||$ 